\title{
Liberty versus Common Good
}

\author{
IVÁN ZOLTÁN DÉNES \\ University of Debrecen, Hungary. E-mail: deniz@iti.mta.hu
}

The functions and territories of academies and universities have never been totally independent from the outside world, nor can we revert to earlier stages of the history of these institutions. Therefore, we have to understand and judge them according to their components in order to find the proper responses to various challenges, and we have to make continuous efforts to be as independent and autonomous as possible in the context of cooperation and the building of collective wisdom. The keywords of this article are personal liberty, political freedom, concentration versus separation of powers, efficiency, meritocracy, common good, and political community.

1.

What does it mean that the outside world is intruding into universities and academies in new forms, mechanisms, and tools in the name of the common good, social and economic development, and relevance? Are they symptoms of new versions of the technocratic concentration of power? Or perhaps they are challenges to the rigid and conservative institutions? Are there cooperations between technocracy and meritocracy under the social and political control of the democratic political community?

The picture is not clear-cut because much contextual information should be taken into account: the different roles of the state, the market and the traditions across countries, from the United States to the United Kingdom, from Germany, Italy and East-Central Europe to China and Japan. ${ }^{1}$ In order to interpret my colleagues' interesting conclusions, I propose an intellectual excursion starting in mid-17th century London, continuing in early 19th century Paris and mid-20th century Oxford, and ending in Budapest in almost the same period. 
2.

On 30 January 1649, Charles Stuart delivered a speech to those standing around the scaffolds waiting for his beheading. Among other things, he said:

For the people, truly I desire their liberty and freedom as much as anybody whomsoever. But I must tell you their liberty and freedom consists in having government - those laws by which their life and their goods may be most their own. It is not to have a share in government. That is nothing pertaining to them. ${ }^{2}$

Is there a difference between the freedom of the citizens of a free state and the freedom of the subjects of a despot?

Hobbes argues that there is no difference between the liberty of the citizens of Lucca and the inhabitants of Constantinople:

There is written on the turrets of the city of Lucca in great characters at this day, the word LIBERTAS; yet no man can thence inferre, that a particular man has more Libertie, or Immunitie from the service of the Commonwealth there, than in Constantinople. Whether a Commonwealth be Monarchical, or Popular, the Freedome is still the same. ${ }^{3}$

By liberty, Hobbes means non-interference. He identifies the domain in which individuals remain free from the state with the area where the state does not intervene. The monstrous state (Leviathan, the sovereign) does exist, he claims, and it has to exist because thereby it can prevent the worst from happening: omnium bellum contra omnes. The area that it leaves free for the individuals is their liberty - liberty does not depend on the nature of the state.

Harrington, on the other hand, claims that there is fundamental difference between the situation in Lucca and that in Constantinople:

For to say that a Lucchese hath no more liberty or immunity from the laws of Lucca than a Turk hath from those of Constantinople, and to say that a Lucchese hath no more liberty or immunity by the laws of Lucca than a Turk hath by those of Constantinople, are pretty different speeches. ${ }^{4}$

The freedom of the citizens of Lucca differs from the liberty of the subjects of the Ottoman sultan because of the political establishment of the two towns. The Lucchese know their freedom is ensured by laws that have to be protected at the cost of their lives. The subjects of the Turkish monarch accept that it is not the laws but the grace of their lord that ensures their freedom. It might be that the sultan will leave them alone if he so desires, but there is no guarantee that he will. It is up to the despot alone to decide what he will do to his subjects: there are no laws to protect them from the tyranny of the ruler.

According to Harrington's thesis, the political community as a whole and its members are free if they are not subjected to anyone's rule. Their political liberty is the precondition for their free community. It ensures that their laws protect 
them, and they, in turn, protect the laws, at the cost of their lives if need be. First of all they protect themselves from being subjugated by others - external conquerors or the grandi ambiziosi, the despotic mighties. The laws protect them from being serfs in bondage so that they can live as free individuals.

\section{3.}

Gentlemen, I wish to submit for your attention a few distinctions, still rather new, between two kinds of liberty: these differences have thus far remained unnoticed, or at least insufficiently remarked. The first is the liberty the exercise of which was so dear to the ancient peoples; the second the one the enjoyment of which is especially precious to the modern nations. If I am right, this investigation will prove interesting from two different angles. Firstly, the confusion of these two kinds of liberty has been amongst us, in the all too famous days of our revolution, the cause of many an evil. France was exhausted by useless experiments, the authors of which, irritated by their poor success, sought to force her to enjoy the good she did not want, and denied her the good which she did want. Secondly, called as we are ... to enjoy the benefits of representative government, it is curious and interesting to discover why this form of government, the only one in the shelter of which we could find some freedom and peace today, was totally unknown to the free nations of antiquity. ${ }^{5}$

That was how Benjamin Constant anticipated the main thesis of his famous lecture at the Athénée Royal in Paris in 1819. The liberty of the ancients was political freedom, i.e. the practice of political rights, of taking an active and permanent part in collective power and of the distribution of social power among all citizens of the state. In public matters, however, the individual had no rights: he was the slave of the community, lost in the nation or the city-state. The small communities of antiquity were involved in incessant hostilities with their neighbours. They were imbued with a militant spirit. Commerce was a matter of lucky accidents, while warfare was their natural state. They were maintained by slaves. The community was so small that the members could assemble in the agora to decide about state affairs. These communities did not know the representative system, which is a modern invention.

The liberty of the moderns means exemption from autocracy and the freedom to influence the government; it means individual freedom, the right to obey only the laws. Modern individuals cannot be arrested, jailed, killed or harassed in any arbitrary manner. They have the right to speak their minds, to choose and pursue their occupations, to use, or even abuse, their property and travel without asking permission. They may gather with others for discussions, religious ceremony, or mere pastime, and they have the right to influence their governments through elections and lobbying.

Freedom from autocracy is personal freedom, the right to dispose over one's life. The freedom of expression, the right to work, to own property, and to travel are personal rights. Modern citizens are entitled to the right to convene, may pursue any 
religion and use their leisure time as individuals. These collective rights, however, simultaneously guarantee individual liberties, as does the freedom to influence the government, the political liberty based on the representative system.

Modern nations sprawl over extensive territories and the number of citizens is large. Therefore, their individual political influence declines almost to naught. The abolition of slavery deprived free citizens of their leisure time and the prevalence of trade excluded all idle periods from their life. Modern nations are civilized and increasingly resemble one another, for they are in permanent trade relations, wars are not profitable for any party, while trade and the commercial outlook becomes increasingly universal. Modern liberty is constituted by the aggregate of the institutional guarantees of pleasures whose function is to ensure the peaceful enjoyment of private independence, the safety of private pleasures. Modern liberty aims at individual happiness, and it is the representative system, the state, that guarantees the attainment of this aim:

What threatened the liberty of the ancients was this: since only guaranteeing the participation in social power was considered important, the individuals squandered their personal rights and pleasures. What jeopardizes the liberty of the moderns is the immersion in the pursuit of individual freedom which leads us to easily resign from the right to participate in political power. ${ }^{5}$

Constant interprets the interrelation of individual and political freedom as end and means. Accordingly, political liberty guarantees individual happiness, as personal happiness is the end and political liberty is the means, a means operated by others whom we only have to supervise. Consumption and economy are superior to politics because the goal of human life is enjoying its pleasures as undisturbed as possible.

On the last three pages of the famous 1819 lecture 'Comparing the Liberties of the Ancients and Moderns', however, the voice of an American founding father appears to speak to us. There, Constant ascribes yet another role to political freedom besides ensuring private happiness: he defines it as the means of improvement.

Happiness is not the only goal of human life. Constant states that man must aim at improvement and moral development, just as much as at happiness. Political freedom is an immense tool of development and moral improvement, since 'it encourages all citizens without exception to examine their most sacred interests, polish their minds, ennoble their thoughts, creating an equality among them that does much credit to a nation and lifts it to become powerful., ${ }^{5}$

The institutions of political liberty are the schools of public intelligence, the workshops of moral dignity, which was proved, Constant notes, by La Fayette's election as deputy.

He ends his argument with a well-nigh republican credo:

Therefore, Sirs, far from renouncing either of the two sorts of freedom which I have described to you, it is necessary, as I have shown, to learn to combine the 
two together. Institutions ... must accomplish the destiny of the human race; they can best achieve their aim if they elevate the largest possible number of citizens to the highest moral position. The work of the legislator is not complete when he was simply brought peace to the people. Even when the people are satisfied, there is much left to do. Institutions must achieve the moral education of the citizens. By respecting their individual rights, securing their independence, refraining from troubling their work, they must nevertheless consecrate their influence over public affairs, call them to contribute by their votes to the exercise of power, grant them a right of control and supervision by expressing their opinions; and, by forming them through practice for these elevated functions, give them both the desire and the right to discharge these. ${ }^{5}$

4.

Do personal freedom and political liberty cancel each other out? Does the abuse of political freedom entail the loss of its legitimacy? Does sacrificing personal freedom increase political freedom? ${ }^{6}$

In Isaiah Berlin's view, it is harder to abuse 'negative' liberty (i.e. immunity from interference) than 'positive' freedom (i.e. self-determination, and self-rule), because positive freedom has been tied to the static and inflexible concept of human nature. ${ }^{7}$ This mentality has led to the false equation of the values of knowledge and freedom.

The sacrifice of individual liberty on the communal altar is an absolute loss that does not enhance the values for which the sacrifice was made. This mode of thinking claims more and more victims. The fear originating from the freedom of choice is replaced by stability based on blind obedience; critical thought by the spirit of the flock; happiness, freedom, and righteousness by a striving for security. All this has led to the unlimited power of professional revolutionaries, specialists, and experts in possession of 'Knowledge' based on supernatural authority. The model of technocratic society envisaged by Auguste Comte has been brought to life by the reign of specialists, the priests of calculemus. The result of this substitution is the ascent of the mystical and magical rule of the omnipotent and omniscient absolutist elite, the technicians of power and the experts. ${ }^{8}$

At the root of Berlin's position is the conviction that personal liberty and political freedom do not cancel each other out, nor can one replace the other. Both have their own justification, and neither one can make up for the other: sacrificing one of them does not result in the stabilization or growth of the other. Neither one can be identified with anything else - not with the other, not with justice, equality or security. However, the place of political liberty was, is, and can be replaced by security, the choice between possibilities by specialist knowledge (actually of a magical character) which features as exclusive and personal freedom by subordination to large organizations.

And so we have come full circle: both kinds of liberty may be sapped by security. 
5.

Below, I quote parts of a lecture held in early 1947 at the Hungarian Academy of Sciences in Budapest by István Bibó (1911-1979). Bibó was a lawyer, a professor of political science, a librarian, and the last legitimate minister of the 1956 revolution who opposed the soviet occupation. He was almost hanged, was sentenced for life, suffered imprisoned for six years, after which he was allowed to work as a librarian again. At the time of delivering his lecture at the Hungarian Academy of Sciences, he was a professor of political science.

Which up-to-date contents could be assigned to the principle of the separation of powers, and which problems of modern statehood could be solved with its help? Which points of modern statehood are threatened with new phenomena or new foci of power concentration?

One of these nodes emerged from the extension of state power into the economy ... The other area in which the demoralizing effect of power concentration is even more formidable is intellectual life, culture. In several respects it is the central issue of statehood today. The importance of science for the state has increased to an unprecedented measure. This entails, on the one hand, that state power strives to influence scientists, first of all natural scientists because of their significance, while on the other hand the often doctrinarian state-related and political stance of social scientists and the naïve positions of natural scientists assume grave economic, strategic and general political significance. Yet, there exists a far greater danger: the - otherwise marvelous and irresistible - expansion of the media of mass culture ... To combat these dangers, several organizational forms have emerged and are emerging. Endowing the body of scientists, artists and educators with similar independence to the judiciary is being given much thought. The new organizational forms of science - though initiated by the state - imply the germs of the self-determination of intellectual life. Science and state power will have to be separated somehow, because mixing up the two will inevitably lead to the utter corruption of intellectual life and cultural production. In this regard, universities and academies are often talked about as institutions protecting their historic autonomy to lesser or greater degrees. They often face the accusation that their autonomy is merely the fixing of certain personal and social lines of forces. That, however, merely means that the academy or the university is too narrow a frame, but what follows from this recognition is not the annihilation of autonomy but its more comprehensive organization; in the whole of culture, in cultural production and mass-scale culture consumption, some apparatus of self-sufficiency must be brought about. It is beyond my scope to analyze the practical aspect of that organization to be built out. Nevertheless, the outlines of a scientific or cultural 'state power' that will have to fight out its autonomy, self-rule, and constitutional separation from power concentration are vaguely taking shape: in the course of history, the judiciary power has successfully underwent a similar change.

The third area in which the danger of corruption is looming large can be summarized as bureaucracy or, more precisely, technocracy. Even if the economic and intellectual scenes were successful to build out a certain level of self-determination and to separate themselves as state powers, the importance of organizing and being 
organized in both general management and economic and cultural management would inevitably increase, together with the power concentration this implies. By an omnipotent bureaucracy I do not mean the backward, strait-laced officialdom with tardiness and inefficiency as its main characteristics, but contrarily a highly successful, effective, operative organization that is in the making from San Francisco to Kamchatka. The decisive role of the specialist and organizer will gradually result in an extremely rationalized 'workshop' in which, apart from the few highly trained organizers and experts, the superficially trained majority will increasingly refuse to undertake the painful and tiresome work of studying and will surrender all control to the managers and experts of the over-rationalized 'mammoth factory'. This perspective holds an inherent threat to human liberty and a potentiality of autocracy that are so great that they cannot be foreseen today. This will be the largest and most demoralizing apparatus of power concentration in the future, against which the only possible counterweight will be democratic political education, professional earnestness, a widened scope of self-government, and an expanded demand for supervision. These measures alone could force this new aristocracy of organizers to withdraw to the place it should occupy.

I am not competent, nor is it possible to put forth concrete proposals for the solution of this problem that obviously belongs to tomorrow. I have faith that the people's instinct for freedom will solve this problem, which is only vaguely perceived now and which is preceded by more immediate and weighty problems of our days. However, it is not useless to sound the alarm, because the fact that the aristocracy of this new power concentration will be the aristocracy of competence and education does not solve the issue but, on the contrary, will make it hard for the sense of freedom to revolt against it. ${ }^{9}$

According to Bibó, freedom has different meanings in different situations, but its essence is the same: self-government, and the absence of concentration of personal and impersonal power.

\section{6.}

Charles Stuart and Hobbes opined that the relation between personal and political freedom is end and means. Harrington's, Arendt's and the neo-republicans' viewpoint was almost the opposite. Constant and Berlin were nearer to the first version than the second, but they thought that both are values having their own territories. Bibó held that they mutually presupposed each other and the rest of the democratic political values, and assayed the new forms of concentration and separation of power.

The picture that our education and social science experts have shown us is definitely not black and white. We can realize that there are challenges to Academia and university. It is convincing that there are different cooperations between researchers and firms, and sometimes they are working together under the social and political control of the democratic political community. Of course we have to be aware that there are symptoms of new versions of technocratic concentration of power, too. Knowing that the functions and territory of Academia 
and university have never been totally independent from the outside world, realizing that we cannot go back to earlier phases of their history and, faced with the challenges, we have to understand and judge them piece by piece to find the responses, and we have to make continuous efforts in order to be as independent and autonomous as possible in the context of cooperation and the building of collective wisdom.

\section{Notes and References}

1. See the contributions by Aarrevaara, Arimoto, Finkelstein, Rostan and Teichler in this issue. Cf. B. Haverhals (2007) The normative foundations of research-based education: Philosophical notes on the transformation of the modern university idea. Studies in Philosophy and Education, 26, pp. 419-432; J. Mittelstraß (2006) The future of the university and the credibility of science and scholarship. Ethical Perspectives: Journal of the European Ethics Network, 13, pp. 171-189; and J. Mittelstraß (2007) Quality assessment in higher education institutions - from the perspective of those assessed. International Journal of Educational Leadership Preparation, 3(1), pp. 37-40.

2. H. R. Williamson (1957) The Day They Killed the King (New York: Macmillan).

3. T. Hobbes (1991) Leviathan, edited by R. Tuck. (Cambridge: Cambridge University Press).

4. J. Harrington (1992) The Commonwealth of Oceana and A System of Politics, edited by J. G. A. Pocock (Cambridge: Cambridge University Press).

5. B. Constant (1988) Political Writings, edited by B. Fontana (Cambridge: Cambridge University Press).

6. This section is based on I. Z. Dénes (2008) Personal liberty and political freedom. Four interpretations. European Journal of Political Theory, 7(1), pp. 81-98, 82-84, partly as an excerpt, partly as a summary.

7. I. Berlin (2000) Freedom and its Betrayal. Six Enemies of Human Liberty, edited by H. Hardy (London: Pimlico).

8. I. Berlin (2002) Liberty, edited by H. Hardy (Oxford: Oxford University Press).

9. I. Bibó (1986-90) Válogatott tanulmányok [Selected essays], second of 4 vols, edited by T. Huszár and I. Bibó, Jr. ( (Budapest: Magvető). Translated by Judit Pokoly for this essay.

\section{Further Reading}

Berlin, I. (2000) Three Critics of the Enlightenment: Vico, Hamann, Herder, edited by H. Hardy (London: Pimlico).

Berlin, I. (2002) The Power of Ideas, edited by H. Hardy (Princeton and Oxford: Princeton University Press).

Berlin, I. (2005) Flourishing: Letters 1928-1946, edited by H. Hardy (London: Pimlico).

Berlin, I. (2006) Political Ideas in the Romantic Age: Their Rise and Influence on Modern Thought, edited by H. Hardy (London: Chatto \& Windus).

Berlin, I. (2009) Enlightening: Letters 1946-1960, edited by H. Hardy and J. Holmes (London: Chatto \& Windus). 
Bibó, I. (1976) The Paralysis of International Institutions and the Remedies: A Study of Self-Determination, Concord among the Major Powers, and Political Arbitration (Hassocks, Sussex: The Harvester Press).

Bibó, I. (1991) Die deutsche Hysterie: Ursachen und Geschichte, translated by H.-H. Paetzke (Frankfurt: Insel Verlag).

Bibó, I. (1993) Misère des petits Etats d'Europe de l'Est, translated by G. Kassai (Paris: Albin Michel).

Gelderen, M. and Q. Skinner (eds) (2002) Republicanism: A Shared European Heritage, 2 vols (Cambridge: Cambridge University Press).

Pettit, P. (1997) Republicanism: A Theory of Freedom and Government (Oxford: Oxford University Press).

Phillipson, N. and Q. Skinner (eds) (1993) Political Discourse in Early Modern Britain (Cambridge: Cambridge University Press).

Pocock, J. G. A. (1975) The Machiavellian Moment: Florentine Political Thought and the Atlantic Republican Tradition (Princeton: Princeton University Press).

Pocock, J. G. A. (1989) Politics, Language, and Time: Essays on Political Thought and History (Chicago and London: The University of Chicago Press).

Pocock, J. G. A. (1990) The Ancient Constitution and the Feudal Law: A Study of English Historical Thought in the Seventeenth Century (Cambridge: Cambridge University Press).

Pocock, J. G. A. (2009) Political Thought and History. Essays on Theory and Method (Cambridge: Cambridge University Press).

Skinner, Q. (1998) Liberty before Liberalism (Cambridge: Cambridge University Press). Skinner, Q. (2002). A third concept of liberty: Isaiah Berlin Lecture. Proceedings of the British Academy, 11(7), pp. 237-268.

Skinner, Q. (2002). Visions of Politics, 3 vols (Cambridge: Cambridge University Press). Skinner, Q. (2008) Hobbes and Republican Liberty (Cambridge: Cambridge University Press).

\section{About the Author}

Iván Zoltán Dénes is a historian of ideas. He focuses on liberalism, conservatism, nationalism, national identity, historiography, political languages, private history and collective memory, personal and collective traumas, and political hysteries and their cures. He has authored 10 books and has edited 12 others. He is Professor, Chair at the Department of Political Theory and History at the Faculty of Law of the University of Debrecen, and founder and president of the István Bibó Center for Advanced Studies of Humanities and Social Sciences in Budapest. He is a member of the Academia Europaea. His most recent book is Conservative Ideology in the Making (Budapest/New York: Central European University Press, 2009). 